\title{
The Exclusion of Indigenous Traditional Knowledge in the Higher Education: The Case of Traditional Medicine and the Mexican Medical Education
}

\author{
Susana Carolina Guzmán-Rosas', Mina Kleiche-Dray2,3, Carlos Zolla4, \\ Ernesto Suaste-Gómez ${ }^{1}$ \\ ${ }^{1}$ PhD Program on Science, Technology and Society, Centro de Investigación y de Estudios Avanzados del \\ Instituto Politécnico Nacional, Mexico City, Mexico \\ ${ }^{2}$ Institut de Recherche pour le Développement, Paris, France \\ ${ }^{3}$ Université Paris Descartes, Paris, France \\ ${ }^{4}$ University Program of Studies of the Cultural Diversity and the Interculturalism, Universidad Nacional \\ Autónoma de México, Mexico City, Mexico \\ Email: sguzmanr@cinvestav.mx
}

Received 1 March 2015; accepted 31 May 2015; published 4 June 2015

Copyright (C) 2015 by authors and Scientific Research Publishing Inc.

This work is licensed under the Creative Commons Attribution International License (CC BY). http://creativecommons.org/licenses/by/4.0/

(c) (i) Open Access

\begin{abstract}
This paper analyzes the level of inclusion of indigenous traditional knowledge about traditional medicine in Mexican medical training, showing an angle of the place that maintains cultural diversity in higher education nationally. Using a quantitative, cross-sectional, exploratory and descriptive design, instruments were applied to survey the 85 institutions registered with the Mexican Association of Colleges and Schools of Medicine (known by its Spanish acronym AMFEM); the data were analyzed quantitatively and qualitatively. Of these institutions, only $27.05 \%$ include teaching about traditional medicine in 36 subjects related to the topic, $50 \%$ of which is optional, $41.66 \%$ of short duration, $52.62 \%$ with few credit hours and, in some cases, with a pejorative orientation. It is noted that the area of the Mexican medical education reflects a broader political problem of asymmetry and inequality between stakeholders and their knowledge, so that the rejection of indigenous traditional knowledge in the Mexican medical education is only a reflection of the many other places where these groups, and their knowledge, have been excluded before.
\end{abstract}

\section{Keywords}

Indigenous Traditional Knowledge, Mexican Medical Education, Traditional Medicine, Intercultural Education, Multiculturalism 


\section{Introduction}

The importance of the indigenous traditional knowledge was recognized by international organizations from the decade of 1990, defining it later as a set accumulated of knowledge, experiences and representations that possess the indigenous populations that have had an ancient history of interaction with the nature (United Nations, Educational, Cultural Scientific and Organization [UNESCO], 2005). In Mexico, the traditional medicine has been positioned as one of the maximum expressions of the indigenous traditional knowledge, obtaining the juridical recognition of the State, who from the limits emitted by the World Health Organization (WHO, 1978, 2002) has considered him to be one of the axes to including in the services and policies of sanitary attention, among them the medical training based on the allopath medicine, also called western, academic, modern (Zolla, 2005) or scientific, that had her first chair in 1578 (Tanck, 1982) and promotes the clinical model based on natural sciences and experimental methodology.

In this way, traditional medicine is a set of beliefs, knowledge, practices and resources, from popular culture, used to solve health problems, beyond or despite a medicine institutionalized by the State (Lozoya, 1989). In the recent history of Mexican medical education, this issue has been studied in a general manner through the chair of Medical Anthropology which emphasizes the culture as a determinant factor of health-disease and the diversity of the systems of attention and treatment that the societies build to solve their sanitation problems. Another notion with which traditional medicine is studied is Interculturalism that as a medical field it serves as the ability to move equally among different knowledge, beliefs and cultural practices of health-disease, life-death and the body in its biological, social and relational dimensions, as Ibacache and Oyarce notes (Ibacache, 1997). Additionally, this has been included in medical education as Alternative Medicine, Complementary Medicine or Indigenous Medical Practice; such names are often used in countries where the dominant health system is based on allopathic medicine, or where traditional medicine has not been integrated into the health system (World Health Organization [WHO], 2002).

This paper analyzes the inclusion of indigenous traditional knowledge about traditional medicine in Mexico’s current medical formation, indicating the characteristics of the different subjects that associated to such theme integrate the study plans of the institutions of national medical education, contextualizing the results in their legal aspects, health, political and social.

As part of the precedents on the topic, found that the Department of Traditional Medicine and Intercultural Development of the Sector of Health and Welfare of Mexico (2002), known by its Spanish acronym SSA, built the program of traditional Mexican medicine academic in the context of medical anthropology to incorporate sociocultural dimension of health-disease in the formation of resources for health, emphasizing the humanistic approach of respect for indigenous care practices then disqualified and trying to lessen the culture shock of students that provide care in indigenous areas; its goal was to integrate the intercultural approach to health care through content on medical anthropology, traditional Mexican medicine, bio-cultural processes and interaction with the patient. Nevertheless, the studies indicate very little about the inclusion of traditional medicine and medical anthropology in careers of medicine in the country. As Campos-Navarro explains (Rosas, 2009) it continues to form an excessive biomedical weight, and even though they have incorporate aspects about anthropology and interculturalism, this has been insufficient. According to this author (2010), the inclusion of Medical anthropology as a subject of medical education took place in 1997 at the School of Medicine of National Polytechnic Institute (known by its Spanish acronym IPN), prior to that had it been integrated into the medical undergraduate program at the National Autonomous University of Mexico (known by its Spanish acronym UNAM) as part of the History and philosophy of medicine, and was until 2010 when this institution was granted its own space denominating it as Medical Anthropology and multiculturalism. For the specific case of the inclusion of traditional medicine in Mexican medical education, no studies were found, only affirmations hat it is often integrated as part of the Medical Anthropology (Campos-Navarro, 2010), but to date there are no specific reports to indicate their level of inclusion in institutions of medical education in the country, it is also not known to what extent the SSA program has been implemented or one alike to include the notions of traditional medicine, medical anthropology and multiculturalism within the training scheme for their students. In this gap the present study found opportunity to realize itself.

In addition, in researches previously developed the medical sector was identified as a set of key players on the issue of traditional medicine, not only for serving as human resources catering health in areas of indigenous coverage, but because in diverse areas and magnitudes they have been decision makers with the power to project 
some directionality to public policy about traditional medicine, scientific research on medicinal plants and attention to the health of indigenous peoples and communities. Such directionality has been a function of how valuable it is considered traditional medicine and medicinal plants as valid objects of study and worthy of being addressed in scientific, political, cultural and public health areas; surely all these aspects are grounded in the university's academic background and there they are recognized as important knowledge. This was reaffirmed by Duarte (2003) stating vocational training as a determinant for which the medical college student does not complement their knowledge with other medical systems unknown and undervalued. It then argues that medical education is a space that among others shows and rates the recognition and real appreciation of cultural diversity, particularly of indigenous traditional knowledge.

\section{Methods}

The design of inquiry of this study was quantitative, cross-sectional, exploratory and descriptive. To collect data, a questionnaire was designed and implemented, applying it as a census to the 85 Institutions registered until June 15, 2012, in the AMFEM (2012), selected to group since a year prior most medical training institutions in the country and for their outstanding contributions to the field. The data was collected and processed in the period August 2012-March 2013, through the information available on the websites of the previously mentioned institutions and in some cases information was requested via email. Access was granted to all programs of study and/ or curriculum maps of the institutions surveyed. The analysis of the data used descriptive statistics and considered the indicators about the indigenous population. As you can see in the Appendix, the questionnaire was conformed for a section of general information about the institution of medical education (status AMFEM, public-private character, degree awarded and geographical location) and another section with 18 questions destined to explore the variables about the inclusion of traditional medicine in the higher medical training (year of origin of the institution or program, the school year curriculum, the name of the courses related with traditional medicine, formative period in which it is given, character of obligation, total duration in hours, overall proportion of credits and legal state recognition of the topic). Finally five institutions were analyzed: one of which integrates this content with greater seniority and other four explicitly includes the denomination of traditional medicine.

\section{Results}

\subsection{Schools and Faculties of Medicine in Mexico}

Of the 85 institutions AMFEM, 54 (63.52\%) are accredited by the mechanisms that the above mentioned Association recognizes, which means they meet the standards of medical education from the National Accreditation System, which promotes curricular actualization oriented to social health needs, based on Bioethics knowledge, scientists, ecological and humanistic vanguards that articulate local and global; the other 31 (36.47\%) institutions mentioned lack the accreditation maintaining the status of their applicants in a phase of self-assessment. Meanwhile, 32 (37.64\%) are private institutions and 53 (62.35\%) public institutions. These institutions do not count with the same parameters for the design or publication of their respective curriculums, 24 (28.23\%) publish full data of their school year curriculum and 61 (71.76\%) omitted some type of information either on the plan year course studies, the division and the breakdown of materials by its categories or the formative nucleus, pointing to include electives or any other detail of the matters referred to.

\subsubsection{Schools and Faculties of Medicine in Mexico}

As you can see in Figure 1, of the 85 institutions AMFEM, only 23 (27.05\%) include matters related to the subject of traditional medicine and 62 were excluded (72.94\%). From the universe of institutions including subject courses related to traditional medicine, 14 are public (60.86\%) and 9 private (39.13\%); this proportion conserves the distribution of public and private institutions registered with AMFEM, but it changes by analyzing each space as their own universe, being $28.12 \%$ in the case of private and $26.41 \%$ for the public sector. Of these 23 institutions one awarded the title of Medical Surgeon and Homeopath, four of Medical Surgeon and Obstetrician and 18 of Medical Surgeon.

The distribution of the AMFEM institutions, according to the year of origin of these or their medical training programs, shows that the period of 1970-79 was the largest generation of centers and/or medical careers, since it opened 32 (37.64\%) of the 85 currently registered with mentioned Association (Figure 2). 


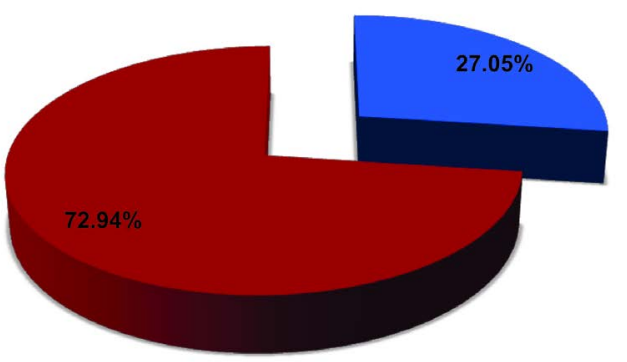

- Included MT

- Do not include MT

Figure 1. Inclusion of Traditional Medicine (MT) in mexican medical education.

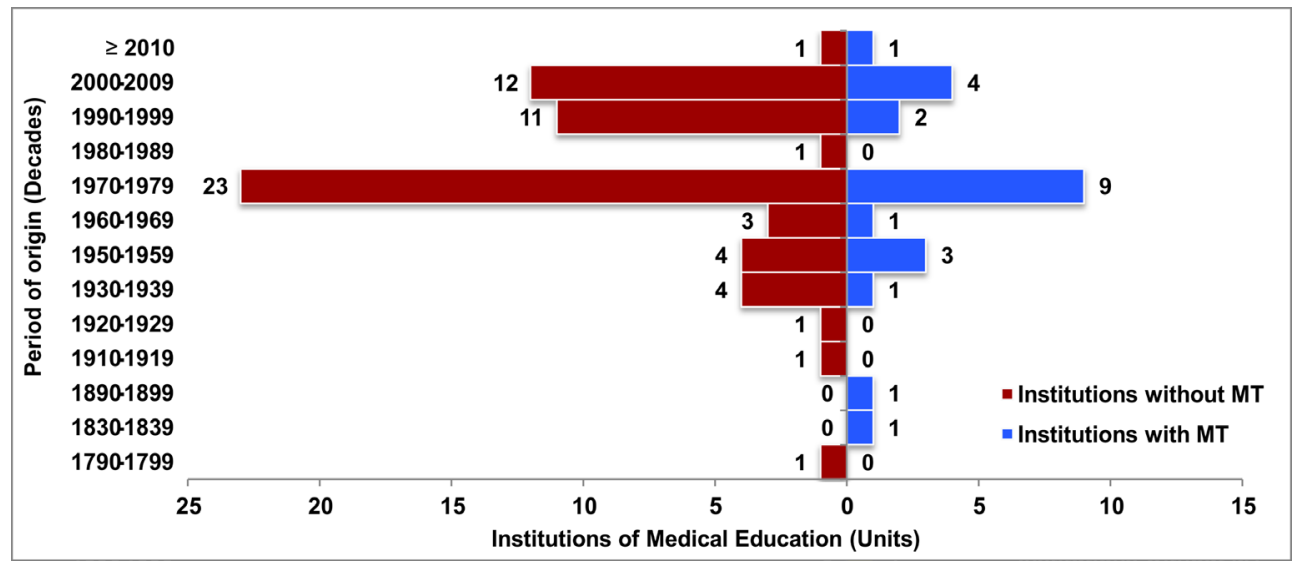

Figure 2. Mexican medical education: institutional origin and inclusion of current Traditional Medicine (MT).

The implementation of traditional medicine in medical training programs, or subject courses associated with it, bears no relation to the indicators linked to the indigenous population. For example, analyzing the case of the 9 states of the Mexican Republic that recorded an indigenous population above $10 \%$ (Table 1), it was found that: Oaxaca had $34.2 \%$ of the indigenous population, $67.4 \%$ of multidimensional poverty and $56 \%$ health coverage, including traditional medicine in only one of the two institutions; meanwhile in Chiapas with $27.2 \%$ of the indigenous population, $78.5 \%$ of multidimensional poverty and $56.8 \%$ coverage on health, includes only two subject courses taught in one of three institutions.

The rest of the states with an indigenous population lower than 10\%, but includes materials of traditional medicine, they do not follow a trend that correlates these indicators, it was observed that: Veracruz with $9.4 \%$ of the indigenous people, includes a subject course related in one of its seven institutions; Tabasco with $3.0 \%$ of the indigenous people, includes five subject courses related in three of its four institutions; the Estado de México with $2.8 \%$ of the indigenous population includes five subject courses listed in two of its four institutions; Morelos with $2.0 \%$ of the indigenous people, includes two subject courses in one of the two institutions; the Distrito Federal with $1.5 \%$ indigenous population, includes 13 subject courses in eight of its 11 institutions and Nuevo León with $1.0 \%$ of the indigenous population, includes three subject courses in three of the four institutions (Figure 3).

In addition, there is legal recognition of traditional medicine in all states whose institutions include it in its medical training. Chiapas, Chihuahua, the Distrito Federal, Guerrero, Morelos, Nuevo León, Puebla and Tabasco recognize it in their health laws, while the Estado de México and Veracruz recognize it in its laws about rights and indigenous culture. However, none of these legislatures encourage institutions to include traditional medicine in their medical education. 
Table 1. Teaching of Traditional Medicine (MT) in the states with larger indigenous population.

\begin{tabular}{|c|c|c|c|c|c|c|}
\hline \multirow[b]{2}{*}{ State } & \multicolumn{6}{|c|}{ Characteristics } \\
\hline & $\begin{array}{l}\text { Indigenous } \\
\text { population }\end{array}$ & $\begin{array}{l}\text { Multidimensional } \\
\text { poverty }\end{array}$ & Health coverage & $\begin{array}{c}\text { Institutions } \\
\text { AMFEM }\end{array}$ & $\begin{array}{l}\text { Institutions } \\
\text { with traditional } \\
\text { medicine }\end{array}$ & $\begin{array}{l}\text { Subject courses } \\
\text { about traditional } \\
\text { medicine }\end{array}$ \\
\hline Oaxaca & $34.2 \%$ & $67.4 \%$ & $56.0 \%$ & 2 & 1 & 1 \\
\hline Yucatán & $30.2 \%$ & $48.5 \%$ & $74.9 \%$ & 2 & 0 & 0 \\
\hline Chiapas & $27.2 \%$ & $78.5 \%$ & $56.8 \%$ & 3 & 1 & 2 \\
\hline Quintana Roo & $16.7 \%$ & $34.6 \%$ & $67.6 \%$ & 1 & 0 & 0 \\
\hline Guerrero & $15.1 \%$ & $67.6 \%$ & $53.3 \%$ & 2 & 1 & 1 \\
\hline Hidalgo & $15.1 \%$ & $54.9 \%$ & $65.3 \%$ & 1 & 0 & 0 \\
\hline Campeche & $12.3 \%$ & $50.3 \%$ & $76.8 \%$ & 1 & 0 & 0 \\
\hline Puebla & $11.7 \%$ & $61.2 \%$ & $49.5 \%$ & 4 & 2 & 3 \\
\hline San Luis Potosí & $10.7 \%$ & $52.6 \%$ & $73.0 \%$ & 1 & 0 & 0 \\
\hline
\end{tabular}

Source: Own elaboration, based in INEGI (2011) and CONEVAL (2012).

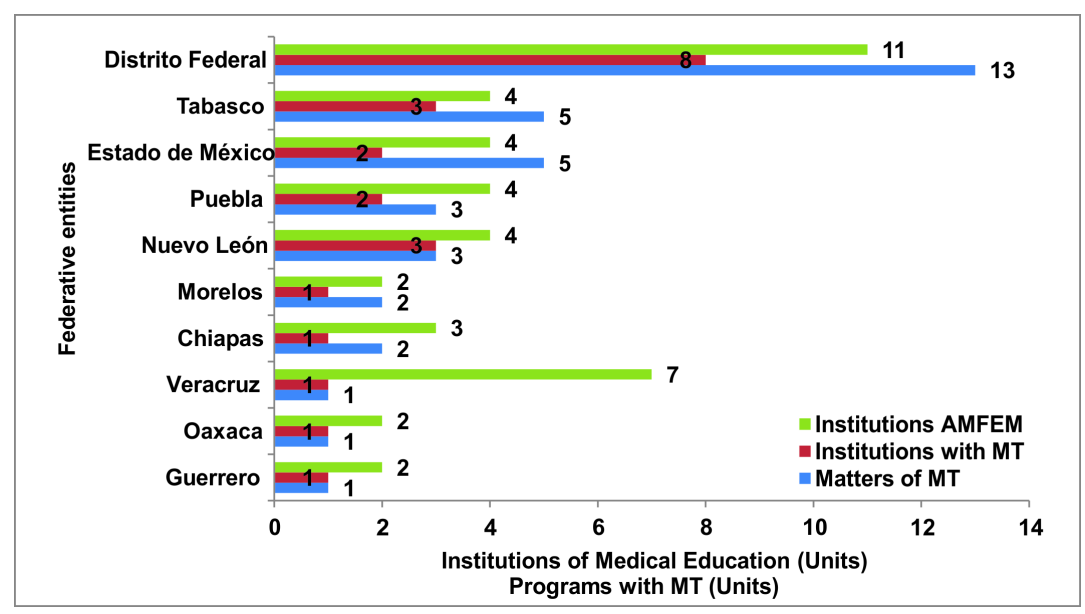

Figure 3. State distribution of programs that include Traditional Medicine (MT).

The 23 institutions that include traditional medicine come up with a total of 36 subject courses (Figure 4), the ones that are most frequency are Medical anthropology, Alternative Medicine, Medical Anthropology and multiculturalism, Mexico: multicultural nation and Contributions of the traditional medicines.

In all these subject courses underlies the general notion of medical thought, by Leon and Berendnson (1996), as a set of concepts, procedures and material resources, designed to prevent and cure diseases; what changes is the particular location that each institution assigns to traditional medicine and the notions associated to that.Of the 36 subject courses associated with traditional medicine, 25\% are taught at the UNAM, while the Olmeca University (known by its Spanish acronym OU), the Autonomous University of the State of Mexico (known by its Spanish acronym UAEM) and the IPN offered another 25\%, the rest is distributed (Figure 5) from the following institutions: University La Salle (known by its Spanish acronym US), Juarez Autonomous University of Tabasco (known by its Spanish acronym UJAT), Autonomous University of Chiapas (known by its Spanish acronym UNACH), University of the Americas Puebla (known by its Spanish acronym UDLA), Latin American University (known by its Spanish acronym ULA), University of Monterrey (known by its Spanish acronym UDEM), Institute of Higher Studies of Monterrey (known by its Spanish acronym ITESM), University Whestill (known by its Spanish acronym UW), University Cristobal Colon (known by its Spanish acronym UCC), Autonomous University of Puebla (known by its Spanish acronym BUAP) Montemorelos University (known by its 


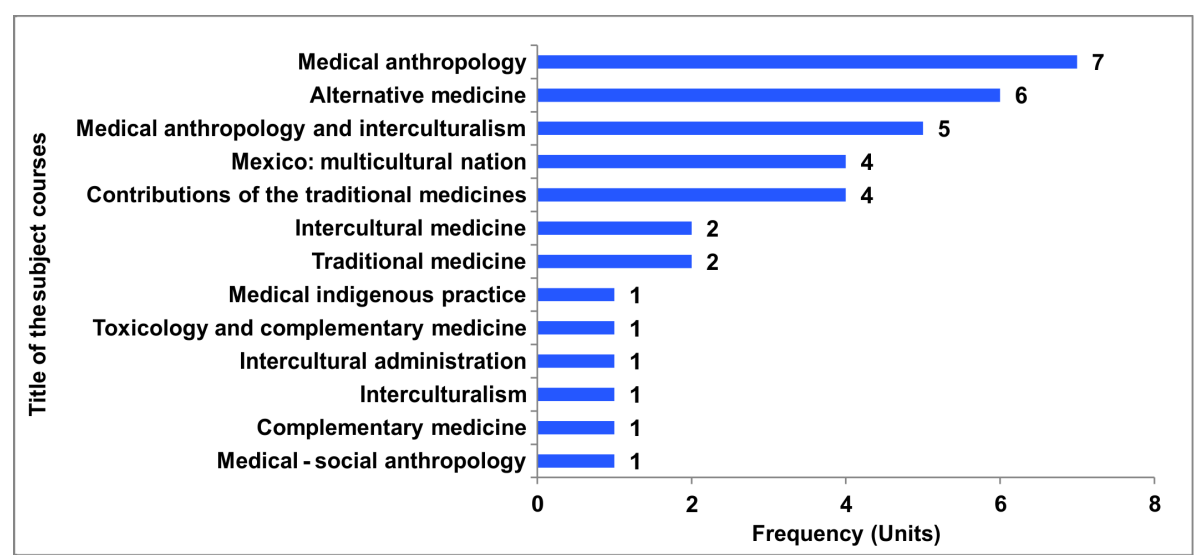

Figure 4. Distribution of subject courses that include Traditional Medicine.

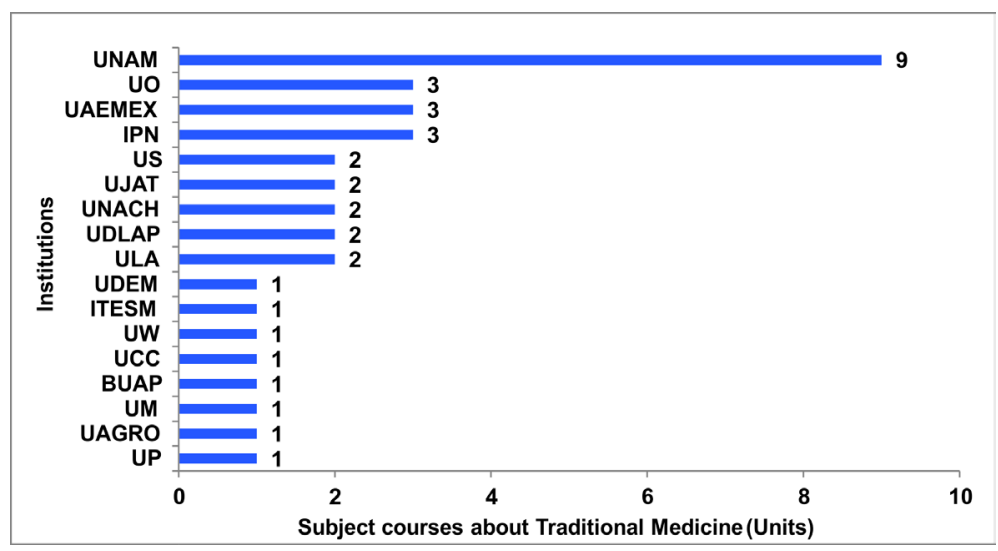

Figure 5. Institutional distribution of subject courses that include Traditional Medicine.

Spanish acronym UM), Autonomous University of Guerrero (UAGRO) and University Pan American (known by its Spanish acronym UP).

It was from 2000 that traditional medicine began to have a space in Mexican medical training, so that 52.7\% of the subject courses associated with it belong to the curriculum and/or programs dating among 2006-2010 (Figure 6).

Although the seventh semester recorded $16.6 \%$ of the subjects courses related to traditional medicine, there is no distribution that establishes stage of instruction in particular.

There is also no regulation on the obligation of such subject courses: $41.6 \%$ were of obligatory enrollment, $50 \%$ in an optional manner and $8.4 \%$ showed no specification. The distribution of hours spent on each of the subjects (Figure 7) shows a Median (Me) of 40 hours, coinciding with the Mode (Mo).

The percentage proportion of credits for each of these subject courses shows the real appreciation of traditional medicine in the comprehensive program of medical education of the institutions; it was found that the most common distribution (Mo) is located in the percentile rank ranged between 0.90 and 0.99 (Figure 8).

\subsubsection{The Case of the Autonomous University of Chiapas}

The medical program UNACH includes a first module which is offered during the first semester and integrates subject courses from Medical anthropology and Indigenous medical practice. This program dates back to 1993, making it the oldest among the 23 that include subject courses related to traditional medicine. In its foundation, such curriculum contemplates areas and of social state demographic characteristics, including indigenous health indicators; however these subject courses have a very small position in the global context of medical training, assigning a single session of two-hour for each case.

1) The subjects with explicit denomination of Traditional Medicine 


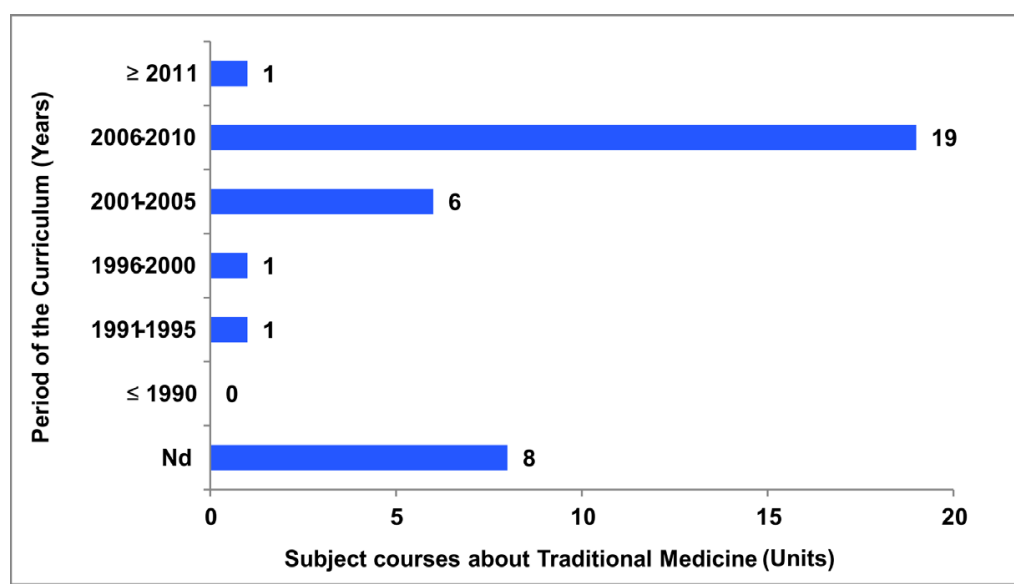

Figure 6. Year of curriculum subject courses that include Traditional Medicine.

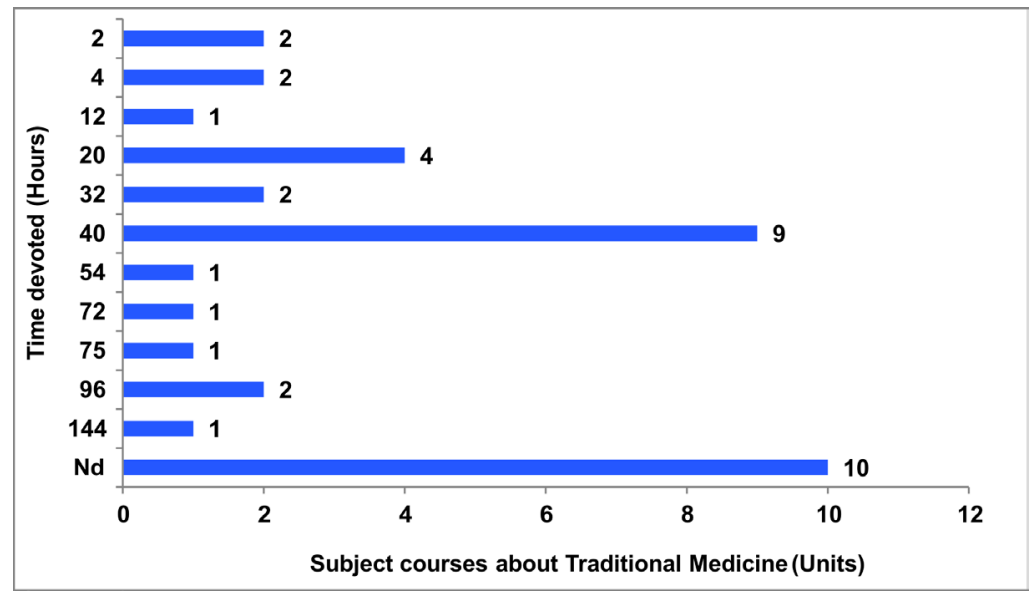

Figure 7. Time devoted to subject courses that include Traditional Medicine.

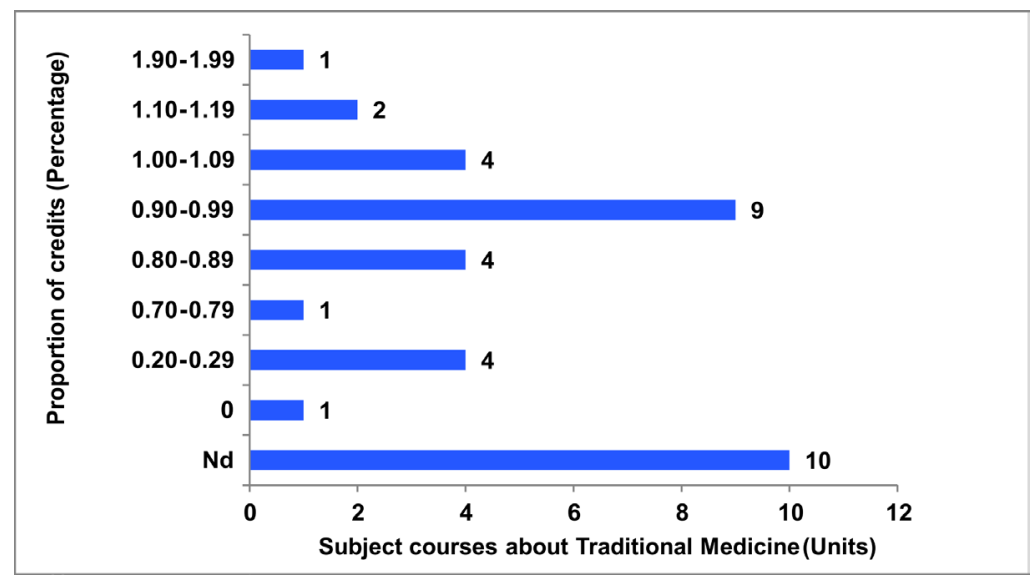

Figure 8. Percentage proportions of credits in subject courses on Traditional Medicine.

There are four institutions offering matters with explicit denomination of Traditional medicine, a total of six subject courses titled as Traditional medicine or Contributions of traditional medicines (Table 2), but the criteria by which they operate are not homogeneous.

In all six cases the whole proportion percentage of credits does not exceed 1\%. Only one of them (given at the 
Table 2. Subject courses with explicit denomination of Traditional Medicine.

\begin{tabular}{|c|c|c|c|c|c|c|c|c|}
\hline \multirow{2}{*}{ Subject } & \multicolumn{8}{|c|}{ Variables } \\
\hline & Institution & $\begin{array}{c}\text { Year } \\
\text { of Origen }\end{array}$ & State & $\begin{array}{l}\text { Title } \\
\text { granted }\end{array}$ & Plan year & $\begin{array}{l}\text { Enrollment } \\
\text { (Core) }\end{array}$ & $\begin{array}{l}\text { Total } \\
\text { Hours }\end{array}$ & $\begin{array}{c}\text { Credits } \\
\text { (Overall \%) }\end{array}$ \\
\hline \multirow{2}{*}{$\begin{array}{l}\text { Traditional } \\
\text { Medicine }\end{array}$} & $\begin{array}{l}\text { UAEMEX } \\
\text { Toluca }\end{array}$ & 1954 & $\begin{array}{l}\text { Estado de } \\
\text { México }\end{array}$ & $\begin{array}{l}\text { Medical } \\
\text { Surgeon }\end{array}$ & 2002 & Optional & 4 & 1.0 \\
\hline & UDEM & 1972 & Nuevo León & $\begin{array}{c}\text { Medical } \\
\text { Surgeon and } \\
\text { Obstetrician }\end{array}$ & - & Obligatory & - & 0.86 \\
\hline \multirow{4}{*}{$\begin{array}{l}\text { Contributions } \\
\text { of the } \\
\text { traditional } \\
\text { medicines }\end{array}$} & $\begin{array}{l}\text { UNAM } \\
\text { Zaragoza }\end{array}$ & 1976 & $\begin{array}{l}\text { Distrito } \\
\text { Federal }\end{array}$ & Medical Surgeon & 2010 & Optional & 40 & 0.92 \\
\hline & $\begin{array}{c}\text { UNAM } \\
\text { University city }\end{array}$ & 1833 & $\begin{array}{l}\text { Distrito } \\
\text { Federal }\end{array}$ & Medical Surgeon & 2010 & Optional & 40 & 0.92 \\
\hline & $\begin{array}{l}\text { UNAM } \\
\text { Iztacala }\end{array}$ & 1975 & $\begin{array}{l}\text { Estado de } \\
\text { México }\end{array}$ & Medical Surgeon & 2010 & Optional & 40 & 0.92 \\
\hline & UO & 2010 & Tabasco & Medical Surgeon & 2010 & Optional & 40 & 0.92 \\
\hline
\end{tabular}

Source: Own elaboration.

UDEM) is mandatory, but has the lowest proportion percentage of credits. The subject courses of greater duration in hours are offered at UNAM and at the UO, located within the optional core Contributions of art and culture and by the influence of the UNAM, both operate with the same model.

\section{Discussion}

After the text edit has been completed, the paper is ready for the template. Duplicate the template file by using the Save As command, and use the naming convention prescribed by your journal for the name of your paper. In this newly created file, highlight all of the contents and import your prepared text file. You are now ready to style your paper.

Most educational institutions that include traditional medicine, in the medical training in Mexico, were created in the second half of the twentieth century (65.21\%), particularly in the early 70's (39.13\%). However, the inclusion took a few more decades, focusing on programs dated before 2001 (72.22\%), especially in the period of 2006-2010 (52.77\%). This could be linked to the impact of national legislative reforms in 2001 and 2006, which recognize the multiculturalism, the right to preserve indigenous, uses and customs, accessing health with use of traditional medicine (Article 2, Constitution of the United States of Mexico, 2012), the which should be promoted, respected, developed and included in the official programs of health (Article 93rd, General Health Act, 1984).

Considering their respective universes, decentralization of higher medical education in Mexico reflects a slight quantitative advantage of private institutions (28.1\%) over the public institutions (26.4\%) related to the teaching of traditional medicine.

There is no positive relationship between the programs of medical education that include traditional medicine and state proportions of indigenous population, poverty and health coverage, however, most of the subject courses associated with the theme (77.77\%) are offered in states between $1 \%$ and $3 \%$ of indigenous population. Thus confirming what was reported by Carranza (2001) on the fact that universities are unrelated to developmental processes and the local reality or regional situation. It also shows a lack of planning and co-operation in the areas of education and health, skipping that established in the said 93rd Article.

The inclusion of associated subject courses with traditional medicine, UNACH probably relates to the impact of institutional programs analyzed by Freyermuth (1993): a) Parallel Medicines driven by the National Indigenous Institute (INI) in 1979 to recognize the indigenous medicine; b) Alternative model of health SSA that between 1983-1985, struggled for the interaction between traditional medicine and institutional medicine; c) the work on the interplay of traditional medicine that began in 1982 the Mexican Institute for the Study of Medicinal Plants (known by its Spanish acronym IMEPLAM); d) that in 1990 the Indigenous Coordinating Centers in Chiapas had at least one program to strengthen traditional medicine. Another factor that may have impacted was the discursive climate on indigenous law since 1985 swept through the Chiapas regions (Miralles, 2004) and subsequently materialized in San Andrés Accords. 
The data found indicates that the effort to include traditional medicine in Mexican medical education is minute: only $27.05 \%$ of the AMFEM institutions include the topic through 36 related subject courses but 50\% of these are optional, thus there is no guarantee that such subject courses are taken; although a significant concentration of these materials reaches or exceeds 40 hours duration (41.66\%) but most subject courses are not completely dedicated to the subject, so the hours spent are lower; in $52.62 \%$ of cases the proportion of credit hours is less than $1 \%$ compared to the overall training program. Consequently, no meaningful implementation of the subject courses and content on traditional medicine in Mexican medical education and thus the low impact of the Department of Traditional Medicine and Intercultural Development SSA, because its program has not been implemented in any of the institutions analyzed. In addition, the documents describing positions or operational strategies of SSA (2001, 2002, S. f. [a], S. f. [b]) to strengthen the relationship between traditional medicine and institutional medicine does not consider the importance of teaching spaces for integrating the medical perspectives of traditional medicine, medical anthropology and interculturalism; in them they rather aspire to a remedial training afterwards.

As Gallardo notes (as cited in Alba, 2009), in the previous thing the disagreement influences between allopathic doctors and traditional doctors. Thus, as Reza explains (as cited in CRÓNICA, 2006), many diverse centers still refuse to address the issue because, they say, it goes against the scientific status and lacks value. But as the WHO (2002) points out, even in countries with ancient history on traditional medicine, many allopathic practitioners have an uninformed skepticism, with reservations and disbeliefs about traditional medicine.

As history shows academic physicians have been as a major obstacle in the development of traditional medicine, it also reveals that the origin of formation of those involved have significantly contributed to the promotion of the subject, it has been precisely by physicians. Therefore, it could be hypothesized that the non-recognition and minute value of traditional medicine into the current medical education does not necessarily reflect a homogeneous position of university medical communities and/ or embedded in political practices, but that of those who have had opportunity to influence or decide on curriculum and health policies. Thus, on a historical level two medical allopathic positions are tracked: a very solid one which strongly rejects traditional medicine saying it has no place in medical practice or scientific research and other weak and without many followers, but at the level of voices and practices has had a significant impact on the recognition of traditional medicine.

Carrillo (2001) shows that academic physicians, from colonial times to the twentieth century, and with little dissent, upheld social class ideas on the indigenous population, including their medical practice and traditional knowledge, assuming themselves as superior to what they called barbaric, ignorant and savage race, publishing scientific materials such arguments and, particularly, influencing the exclusionary policies of the State. As Morales notes (as cited in Cano, 2001), during the twentieth century, Othon de Mendizabal and Aguirre Beltrán struggled for the indigenous care by training rural physicians that surpassed the contrast between different medical systems, but the idea failed because of the refusal of a sector of academic physicians who considered an intrusion into scientific activity.

As Hinke (2012) and Zolla (personal communication, March 28 2012) shows, this dichotomy can also be located in the most significant moments of scientific institutionalization of traditional knowledge of indigenous medicine, which were developed at the National Medical Institute (known by its Spanish acronym IMN) and IMEPLAM whose reach steadily encountered the obstacle of allopathic medical posture.

The publications on the subject also reflect the diversity of postures within the scientific medical community, an example is the volume called Scientific medicine/ traditional medicine, published in the journal Ciencias, which alluded various appreciations of allopathic physicians; so while Lozoya (1989) promoted the importance of traditional medicine, Pérez Tamayo (1989) the disqualified it stating that recognize the coexistence of different medicines did not give them all the same efficiency, rationality and credibility because only scientific medicine is objectively valid, calling the others medical practices a therapeutic carnival.

As the WHO (2002) points out, a substantial majority of allopathic physicians emphasize their scientific approach affirming that is free of cultural value and brans, statement that might be worth rethinking in light of the sociology of science. Because the medical academic system is devoid of conceptual elements of the traditional medical system and epistemological understanding of these systems, enhancing their dismissal, lack of intercultural health, stigma and lack of sensitivity of agents and areas of the medical field, included in the health sciences (Beltrán and Castro, 2006).

The resistance of the academic health institutions, to include the issue is attributed to a deep and daily social class struggle (Lozoya, 2005), being the power and domination that prevent the articulation between traditional 
and academic medical systems (Beltrán and Castro, 2006). Thus, universities fuel and differentiate between these two systems (Lozoya and Zolla, 1984); ignoring that traditional medicine is supported by an ancient practice that emerged within the communities themselves (Zolla, 2005). It then a deals with an inclusion, paradoxically exclusionary, as Maturana shows (Beltrán and Castro, 2006), where other’s presence is temporarily admitted, tolerating an epistemological error, leading to the delayed denial of intercultural relations, where the recognition of others as inferior is always a form of domination.

\section{Conclusion}

There exists an effort to integrate traditional medicine in Mexican medical education, but this is not really significant, in addition, some of the institutions that include it assume a character superiority over such knowledge, in other cases they do in a logic of scientifization (Agrawal, 2002), which aims to put traditional medicine in the mold of academic medicine to give it a character of alleged truth, such as program of Intercultural Medicine UJAT (2010, p. 4) that includes the goal of "thinking about the kinds of medicine to which people turn in times of crisis in cultural, economic and values”, also giving a title to one of their units Traditions rooted in the indigenous cultures and in people of poor medical culture; in these cases, it is included to control or deny, which shows a particular institutional ownership which contradicts the notion of teaching about intercultural health.

The findings of this study show that in Mexico the goal of WHO (2002), projected for 2000-2005, about the basic training in traditional medicine and allopathic practitioners authorized to exercise was not reached. Thus, despite the fact that traditional medicine has its own place in the national legal instruments and it is also one of the most deeply rooted traditions and expressions of indigenous culture, there is not enough significant validation for inclusion in the medical education and take advantage their knowledge in the coverage of the National Health System, which appeared as an axis point of the Program of action: health and nutrition for indigenous people (2010) emanated from the National Development Plan 2001-2006 (Fox, 2001) and the Program for the Development of Indigenous People 2009-2012 decreed under the National Development Plan 2007-2012 (Calderón, 2007).

There is thus a contradiction between the real and the ideal of multiculturalism led in Mexico to the field of medical education, on the one hand we have a society that drives their ideals in a speech of pride and appreciation to indigenous tradition, but on the other, it is adamantly opposed to include their medical practices. Thus, Mexico seems to have a tolerant system, in the sense managed by the WHO (2002), because its national health system is significantly based on allopathic medicine, but by law tolerates some practices of traditional medicine.

Finally, it can be argued that no meaningful inclusion of traditional medicine in Mexican medical education has to do with at least two unavoidable issues: the first is an epistemological split between the systems of knowledge that led to traditional medicine and the practice of allopathic medicine, since the first group place the medicine as part of a cultural framework of worldviews and ritual practices, while the second group base themselves on the scientific method of experimental cut taken in the academic space; this is important explanation for understanding the differences in practices, healing methods and the alleged impossibility of reconciliation between both systems. But the issue cannot be exhausted here, however in the contrary, we must argue that the underlying problem in not significantly including the traditional medicine practices in Mexican medical education is undeniably political, since indigenous groups and their traditional knowledge occupy a unfavorable place in the distribution of Mexican power, so that the rejection of such knowledge in the medical education is only a reflection of the many other places where these groups, and their knowledge, have been excluded before.

Consequently, it is in this aspect of domination and inequality where the focus could have the greatest impact on the subject, because it is not about idealistic assertions expressed irresponsibly, various studies indicate that local cultural characteristics reflect the economic and political position that occupy a society within a larger system (Kottak, 2011), and if that were not enough, national and international indicators officially confirm the unequal position in which the Mexican indigenous population live under, as the National Council of Evaluation of the Policy of Social Development (known by its Spanish acronym CONEVAL, 2012), the National Institute of Statistics and Geography (known by its Spanish acronym INEGI, 2011), the National Council of Population (known by its Spanish acronym CONAPO, 2011) and the United Nations Development Programme (UNDP, 2010) indicates in his different studies.

\section{Acknowledgements}

Study realized in the frame of PhD Program on Science, Technology and Society of Cinvestav-IPN (Av. Insti- 
tuto Politécnico Nacional 2508, Col. San Pedro Zacatenco, Delegación Gustavo A. Madero, Apartado Postal 14-740, 07000 México, D.F., México. Telephone: +52 (55) 57473800, Ext. 6780) and the project Environmental Governance in Latin America and the Caribbean (ENGOV) 2011-2015 (FP7-SSH-2010-3/SSH.2010.4.1-2). Guzmán-Rosas thanks Consejo Nacional de Ciencia y Tecnología (Conacyt).

\section{References}

Agrawal, A. (2002). El conocimiento indígena y la dimensión política de la clasificación. Revista Internacional de Ciencias Sociales, 173, 6-18.

Alba, É. (2009). Es necesario reconciliar a los médicos de bata blanca y los tradicionales. La Jornada Michoacán.

Calderón, H. (2007). Plan Nacional de Desarrollo 2007-2012 (pp. 1-323).

http://pnd.calderon.presidencia.gob.mx/index.php?page=documentos-pdf

Campos-Navarro, R. (2010). La enseñanza de la antropología médica y la salud intercultural en México: Del indigenismo culturalista del siglo XX a la interculturalidad en salud del siglo XXI. Revista Peruana de Medicina Experimental en SaludPública, 27, 114-122. http://www.scielo.org.pe/pdf/rins/v27n1/a16v27n1.pdf

http://dx.doi.org/10.1590/S1726-46342010000100016

Cano, S. (2001). Reseña del libro Medicina tradicional en México. Dimensión Antropológica, 26. http://www.dimensionantropologica.inah.gob.mx/?p=852

Carranza, S. (2001). Complementariedad entre agentes del desarrollo. http://www.eurosur.org/isf/conf2001/mesacarr.pdf

Carrillo, A. (2001). Los médicos y la degeneración de la raza indígena. Ciencias 60-61, 64-70. http://www.ejournal.unam.mx/cns/no60-61/CNS06011.pdf

Constitution of the United States of Mexico (2012). http://www.diputados.gob.mx/LeyesBiblio/pdf/1.pdf

CRÓNICA (2006). Por debajo del agua, médicos alópatas recomiendan tratamientos alternativos. http://www.cronica.com.mx/notas/2006/219003.html

De Tanck, E. (1982). La Colonia. Historia de las profesiones en México (pp. 5-68). México: El Colegio de México.

Department of Traditional Medicine and Intercultural Development of Mexican SSA (2002). La medicina tradicional mexicana en el contexto de la Antropología Medica en los planes de estudio de escuelas y facultades de medicina en México. http://www.salud.gob.mx/unidades/cdi/documentos/medicina_tradicional_mexicana.pdf

Duarte, G. (2003). Medicina occidental y otras alternativas: ¿es posible su complementariedad? Cadernos de Saúde Pública, 19, 635-643. http://www.scielo.br/pdf/csp/v19n2/15429.pdf

Fox, Q. (2001). Plan Nacional de Desarrollo 2001-2006. http://www.sagarpa.gob.mx/ganaderia/Publicaciones/Lists/Otros/Attachments/4/PND0106.pdf

Freyermuth, E. (1993). Médicos tradicionales y médicos alópatas: Un encuentro difícil en los altos de Chiapas.

General Health Mexican Act (1984). http://www.diputados.gob.mx/LeyesBiblio/pdf/142.pdf

Hinke, N. (2012). El Instituto Médico Nacional: La política de las plantas y los laboratorios a fines del siglo XIX. In C. Laura (Ed.), México: Cinvestav/ UNAM.

Ibacache, B. (1997). La salud, el desarrollo y la equidad en un contexto intercultural.

http://www.mapuche.info/mapuint/ibaca00.htm

Kottak, C. (2011). ¿Qué es la antropología? In Antropología Cultural (pp. 1-21). México: Mac Graw-Hill.

León, B., \& Berendnson, S. (1996). Medicina teórica. Definición de la medicina y su relación con la biología. Revista Medica Herediana, 7, 1-4. http://www.scielo.org.pe/pdf/rmh/v7n1/v7n1e1.pdf

Lozoya, L. (1989). La medicina tradicional en la realidad político-social de México. Ciencias, 14, 27-33. http://www.revistacienciasunam.com/images/stories/Articles/14/CNS01404.pdf

Lozoya, L. (2005). La verdadera y triste historia de la investigación de la flora usada en las medicinas indígenas de América Latina. (Donde se dice lo que pasó 25 años después de escuchar los cuentos de la OMS). Revista de Fitoterapia, 5, 21-26. http://www.fitoterapia.net/revista/pdf/RDF5_Supl1_PL.pdf

Lozoya, L., \& Zolla, L. (1984). Medicina Tradicional en México. Boletín de la Oficina Sanitaria Panamericana. http://hist.library.paho.org/Spanish/BOL/v96n4p360.pdf

Mexican Association of Colleges and Schools of Medicine (AMFEM) (2012). Directorio de asociados y avances en la acreditación. http://www.amfem.edu.mx/directorio

Miralles, S. (2004). Formación del EZLN. Revista Pegada, 5, 31-41. http://revista.fct.unesp.br/index.php/pegada/article/view/1282/1278

National Commission for the Development of the Indigenous Peoples (2010). Programa para el Desarrollo de los Pueblos 
Indígenas 2009-2012. http://www.cdi.gob.mx/index.php?option=com_docman\&task=doc_details\&gid=114\&Itemid=65

National Council of Evaluation of the Policy of Social Development (2012). Informe de pobreza en México, el país, los estados y sus municipios 2010.

http://web.coneval.gob.mx/Informes/Coordinacion/INFORMES_Y_PUBLICACIONES_PDF/Informe_de_Pobreza_en_M exico_2010.pdf

National Council of Population (2011). Índices de marginación por entidad federativa, 2010.

http://www.conapo.gob.mx/work/models/CONAPO/indices_margina/mf2010/CapitulosPDF/1_4.pdf

Parra, B., \& Castro, P. (2006). ¿Monólogo o diálogo intercultural entre sistemas médicos? Un reto educativo para las ciencias de la salud. Revista Ciencias de la Salud, 4, 110-121.

http://www.scielo.org.co/scielo.php?script=sci_arttext\&pid=S1692-72732006000200013

Pérez, T. (1989). La medicina alopática y las otras medicinas. Ciencias, 14, 22-26. http://www.revistacienciasunam.com/images/stories/Articles/14/CNS01403.pdf

Rosas, B. (2009). Los retos de la salud intercultural. Diálogo con Roberto Campos. Revista Aquí estamos, 6, 44-51. http://ford.ciesas.edu.mx/downloads/Revista11.pdf

Sector of Health and Welfare of Mexico (2001). Programa de acción: salud y nutrición para los pueblos indígenas. http://www.salud.gob.mx/unidades/dgpfs/pueblosindigenas/Pueblos\%20Indigenas.pdf

Sector of Health and Welfare of Mexico (2002). El enfoque intercultural: Herramienta para apoyar la calidad de los servicios de salud. http://www.dgplades.salud.gob.mx/Contenidos/Documentos/Interculturalidad/EnfoqueIntercultural.pdf

Sector of Health and Welfare of Mexico (S. f. a). Fortalecimiento y desarrollo de la medicina tradicional mexicana y su relación intercultural con la medicina institucional. www.salud.gob.mx/unidades/cdi/documentos/DOCSAL7541.doc

Sector of Health and Welfare of Mexico (S. f. b). Salud y nutrición para la población marginada rural e indígena. http://www.salud.gob.mx/unidades/dgpfs/pueblosindigenas/Pueblos\%20Indigenas.pdf

United Nations Development Programme (2010). Informe sobre desarrollo humano de los pueblos indígenas de México. El reto de la desigualdad de oportunidades. http://planipolis.iiep.unesco.org/upload/Mexico/Mexico HDR 2010.pdf

United Nations, Educational, Cultural Scientific and Organization (2005). Conocimientos Tradicionales. http://www.unesco.org/bpi/pdf/memobpi48_tradknowledge_es.pdf

World Health Organization (1978). Promoción y desarrollo de la medicina tradicional. Informe Técnico No. 622. http://whqlibdoc.who.int/trs/WHO_TRS_622_spa.pdf

World Health Organization (2002). Estrategia de la OMS sobre medicina tradicional 2002-2005. http://apps.who.int/iris/bitstream/10665/67314/1/WHO_EDM_TRM_2002.1_spa.pdf

Zolla, C. (2005). La medicina tradicional indígena en el México actual. Arqueología Mexicana XIII, 74, 62-65. 


\section{Appendix}

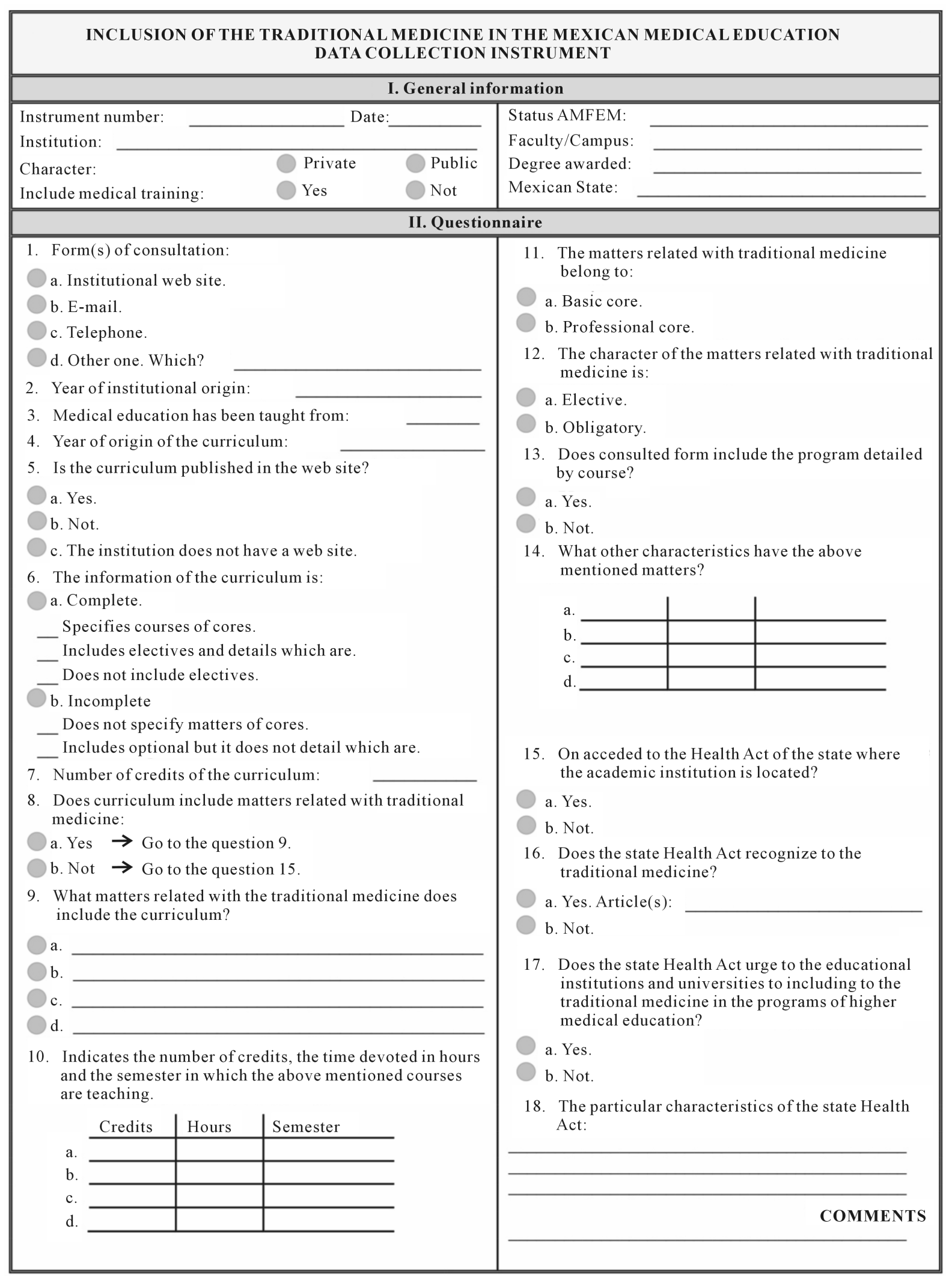

